\title{
Resurgent Parenthood: Organic Domestic Ideals and the Southern Family Roots of Conservative Ascendancy, 1980-2005
}

Gwendoline M. Alphonso

Fairfield University, galphonso@fairfield.edu

Follow this and additional works at: https://digitalcommons.fairfield.edu/politics-facultypubs Copyright 2016 University of Chicago Press Journals

The final publisher PDF has been archived here with permission from the copyright holder.

\section{Repository Citation}

Alphonso, Gwendoline M., "Resurgent Parenthood: Organic Domestic Ideals and the Southern Family Roots of Conservative Ascendancy, 1980-2005" (2016). Politics Faculty Publications. 27.

https://digitalcommons.fairfield.edu/politics-facultypubs/27

\section{Published Citation}

Alphonso, Gwendoline M. "Resurgent Parenthood: Organic Domestic Ideals and the Southern Family Roots of Conservative Ascendancy, 1980-2005." Polity 48, no. 2 (April 2016): 205-223.

This item has been accepted for inclusion in DigitalCommons@Fairfield by an authorized administrator of DigitalCommons@Fairfield. It is brought to you by DigitalCommons@Fairfield with permission from the rightsholder(s) and is protected by copyright and/or related rights. You are free to use this item in any way that is permitted by the copyright and related rights legislation that applies to your use. For other uses, you need to obtain permission from the rights-holder(s) directly, unless additional rights are indicated by a Creative Commons license in the record and/or on the work itself. For more information, please contact digitalcommons@fairfield.edu. 


\title{
Resurgent Parenthood: Organic Domestic Ideals and the Southern Family Roots of Conservative Ascendancy, 1980-2005
}

\author{
Gwendoline M. Alphonso \\ Fairfield University
}

Accounts that focus on the "southernization" of the Republican Party and the subsequent conservative ascendance in American party politics emphasize the role of race and civil rights issues, or battles over sex and gender, but none analyze the significance of family in shaping this partisan rightward shift. Meanwhile, literatures in fields other than party politics have engaged family more centrally, highlighting the rising salience of parents to legal and political development. This article connects and contributes to these literatures by analyzing the impact of parenthood and family on political party development. I demonstrate the increasing salience of "parents" as a political ideal in late twentieth-century policy discourse, reveal an overarching organic family frame in which it was used, and trace this frame to Southern domestic ideals and to the growing importance of the South to the Republican Party. In so doing I provide a "family-centered" account of the late twentieth-century conservative ascendancy and suggest the centrality of family - and parenthood - in defining it.

Keywords family politics; American political development; history of political parties; conservatism; U.S. South

Party politics in the last five decades is conventionally explained as a result of the transition of southern whites from the Democratic to the Republican Party. In many accounts the shift in Republican ideology was part of a long-term "Southern Strategy" that began with the nomination of Barry Goldwater in 1964. Whereas most accounts that focus on the "southernization" of the Republican Party and subsequent conservative ascendance in American party politics emphasize the

I am indebted to Carol Nackenoff for invaluable guidance and comments on a previous version of this manuscript and to Eileen McDonagh, Julie Novkov, Priscilla Yamin and Alison Gash for their irreplaceable support. Thanks also to two anonymous reviewers for Polity for their excellent feedback and suggestions. 
role of race and civil rights issues, ${ }^{1}$ others also connect the phenomenon to battles over sex and gender. ${ }^{2}$ None, however, analyze the significance of family in shaping this partisan rightward shift.

A growing corpus of literature in fields other than party politics engages family more centrally, demonstrating the changes in law and society engendered by the massive demographic transformations in the American family that began in the 1970 s. $^{3}$ One aspect that has been highlighted is the rising salience of parents in legal and political development. Legal scholar June Carbone in her book From Partners to Parents, describes a "second revolution in family law," a paradigm change that occurred as custody decisions shifted from emphasizing spousal relationships to parental ones. She suggests that the fracturing of the nuclear family led to an increased focus on parent-child relationships and asserts that "the code of family responsibility is being written in terms of the only ties left - the ones to children." Other scholars stress the significance of the resurgent parent, as a political subject, on other political developments. For instance, in the transformation of the gay rights movement into the marriage equality movement, advocates are observed to have "put forth gay and lesbian couples as parents in order to secure them legal rights as married partners."

1. For example, see Earl Black and Merle Black, The Rise of the Southern Republicans (Cambridge, Mass: Harvard University Press, 2003); Joseph E. Lowndes, From the New Deal to the New Right: Race and the Origins of Modern Conservatism (New Haven, Conn.: Yale University Press, 2009); Dan T. Carter, From George Wallace to Newt Gingrich: Race and the Conservative Counterrevolution, 1963-1994 (Baton Rouge: Louisiana State University Press, 1999.

2. See, for example, Robert Self, All in the Family: The Realignment of American Democracy (New York: Hill and Wang, 2012); Christina Wolbrecht, The Politics of Women's Rights: Parties, Positions, and Change (Princeton, N.J.: Princeton University Press, 2001); Kira Sanbonmatsu, Democrats, Republicans and the Politics of Women's Place (Ann Arbor: University of Michigan Press, 2003); Jo Freeman, A Room at a Time: How Women Entered Party Politics (Lanham, Md.: Rowman \& Littlefield, 2002); Catherine E. Rymph, Republican Women: Feminism and Conservatism from Suffrage Through the Rise of the New Right (Chapel Hill: University of North Carolina Press, 2009).

3. See, for example, in history, Self, All in the Family (see previous note); J. Brooks Flippen, Jimmy Carter, the Politics of the Family, and the Rise of the Religious Right (Atlanta: Georgia University Press, 2011); Stephanie Coontz, Marriage, a History: From Obedience to Intimacy or How Love Conquered Marriage (New York: Viking, 2005); Natasha Zaretsky, Direction Home: the American Family and the Fear of National Decline, 1968-1980 (Chapel Hill: University of North Carolina Press, 2007). For a notable exception in political science, see Patricia Strach, All in the Family: The Private Roots of American Public Policy, (Stanford, Calif.: Stanford University Press, 2007). For a comprehensive review of recent work on family in political theory and American politics, see Brian Duff, "Family and Citizenship in Political Theory and Political Science," Journal of Family Theory \& Review 6 (2014): 45-59.

4. June Carbone, From Partners to Parents: The Second Revolution in Family Law (New York: Columbia University Press, 2000), xiii.

5. Stu Marvel, "The Evolution of Plural Parentage: Applying Vulnerability Theory to Polygamy and Same-Sex Marriage," Emory Law Journal, 64 (2015): 2048-88, at 2054; and Yvonne Zylan, States of Passion: Law, Identity and the Social Construction of Desire (New York: Oxford University Press, 2011), $24-50$. 
Political scientists document the current impact of parenthood on voting behavior, political beliefs, and public opinion. ${ }^{6}$ Recent works, in particular, suggest the durability of motherhood and shifts in it, as a frame for organizing political participation and shaping political attitudes. ${ }^{7}$ Jill Greenlee, for instance, finds that although "political parties continue to view women through the lens of motherhood in presidential politics," since the second-wave women's movement, motherhood has come to advocate "specific policy issues," and is less a "general" category of appeal in presidential campaigns. ${ }^{8}$

This article contributes to this literature on the changing impact of parenthood and family by connecting it to political party development. I demonstrate the increasing salience of "parents" as a political ideal in late twentieth century policy discourse, reveal an overarching organic family frame in which it was used, and trace this frame to southern domestic ideals and to the growing importance of the South to the Republican Party. In so doing I provide a "family-centered" interpretation of the twentieth-century conservative ascendancy and suggest the centrality of family - and parenthood - in defining it.

The narrative that follows is organized into two sections: the first uses evidence from bill sponsorships and committee hearings to show how "family" and "parents" were deployed by conservatives in the last two decades of the twentieth century. The second section uses aggregate data compiled from real-life family anecdotes cited by legislators during congressional committee hearings ${ }^{9}$ to

6. Laurel Elder and Steven Greene, The Politics of Parenthood: Causes and Consequences of the Politicization and Polarization of the American Family (Albany: State University of New York Press, 2012); Robert Urbatsch, Families' Values: How Parents, Siblings, and Children Affect Political Attitudes (New York: Oxford University Press, 2014), 21-42.

7. Jill S. Greenlee, The Political Consequences of Motherhood (Ann Arbor: University of Michigan Press, 2014); Cynthia Stavrianos, The Political Uses of Motherhood in America (New York: Routledge, 2015); Kristin A. Goss, The Paradox of Gender Equality: How American Women's Groups Gained and Lost Their Public Voice (Ann Arbor: University of Michigan Press, 2013).

8. Greenlee, Political Consequences of Motherhood, 11, 72 (see previous note).

9. I located family-related hearings from 1980 to 2006 from the Congressional Universe database by using family and domestic relations keywords comparable to those used in party platforms and bills, yielding 554 family-related hearings. I manually examined hearing transcripts to identify real-life family narratives. Each case when a member of Congress interacted with a family narrative through questions or comments and raised a policy issue was coded as one case in the data set. By so doing I compiled a data set of 1102 such family cases or anecdotes that members of Congress had referred to. I coded each case for characteristics of the family: region and city of residence, family size, income, population density of city/ town of residence, addictions of family members, civic participation, receipt or not of welfare services, religious identification, working and marital status of parents; I also coded the characteristics of the congressperson, namely: party, committee name, state, and region. In this way, I am able to empirically connect idealized family characteristics to members of Congress and, in the aggregate, to their parties. For more on this methodology, details of findings in this and other historical periods, and my argument about the development of family as an evolving political ideal across the Progressive, Post World War II, and latetwentieth century periods, see Gwendoline Alphonso, Polarized Families, Polarized Politics: Sectional Families, Political Parties \& the Emergence of Culture Wars in America, 1900-2005 (University of Pennsylvania Press, forthcoming). 
empirically demonstrate the roots of New Right Republican ideology in the Southern family. By so doing, I provide an explanation of why parents emerged as a central politicized ideal, suggesting that their heightened salience was a vital part of the Republican southern strategy.

\section{The Resurgence of Parents and the Revival of Southern Organic Domestic Ideals}

The late twentieth century witnessed the unraveling of the nuclear family. In 1960, over $70 \%$ of American households were made up of a breadwinner father, homemaker mother, and their biological children. ${ }^{10}$ Three decades later, such "traditional" nuclear families accounted for less than $25 \%$ of the nation's households. ${ }^{11}$ In what has been described as a massive "demographic transition," the United States moved from a period of relatively high fertility to one with rising ages at marriage, growing rates of cohabitation, increases in single person households, declining remarriage rates, fertility postponement, and higher rates of childlessness. $^{12}$

Accompanying these demographic shifts, Republicans and Democrats increasingly invoked the family as a frame for their policy agendas. As seen in Figure 1, the parties increased their attention to the family beginning in 1968; by 2012, they had tripled the proportion of platform paragraphs in which they addressed the family. ${ }^{13}$

A similar rise in attention occurred in congressional hearings. By the last decade of the twentieth century, lawmakers were introducing an average of 125 family-related bills per Congress (1989-2004), compared with an average of 91 family bills per Congress in the immediate postwar period (1945-1954) and 49 such bills per Congress in the Progressive era (1899-1921). ${ }^{14}$

10. Steven Mintz and Susan Kellogg, Domestic Revolutions: A Social History of American Family Life (New York: Free Press, 1988), 203.

11. Ibid., 203.

12. Ron Lesthaeghe and Lisa Niedert, "The Second Demographic Transition in the United States: Exception or Textbook Example?" Population and Development Review 32 (December 2006): 669-98; see also Naomi Cahn and June Carbone, Red v. Blue Families: Legal Polarization and the Creation of Culture (New York: Oxford University Press, 2010), 34-35.

13. I analyzed Republican and Democratic platforms from 1900 to 2012, yielding 58 primary documents consisting of 17,489 paragraphs in all. Using the platform paragraph as my unit of analysis, each was coded as a "family paragraph" if it addressed the family (as a unit, or parents, children, and spouses as members of a family) through a coherent and discernable policy issue. I defined paragraphs as being delimited by a hard return; thus, they were as short as one to two sentences or as long as many sentences. I excluded planks that addressed women or children as individuals and not in their familial capacity, relation, or role. For more details on the evolution of family as a policy issue in party platforms and bill sponsorship, see Alphonso, Polarized Families, Chapter 1 (see note 9 above).

14. I identified family-related bills by examining each year's Congressional Record Index and searching under index headings that corresponded to family keywords found in concurrent platform 
Figure 1

Family Paragraphs in Party Platforms as Percentage of Total Paragraphs

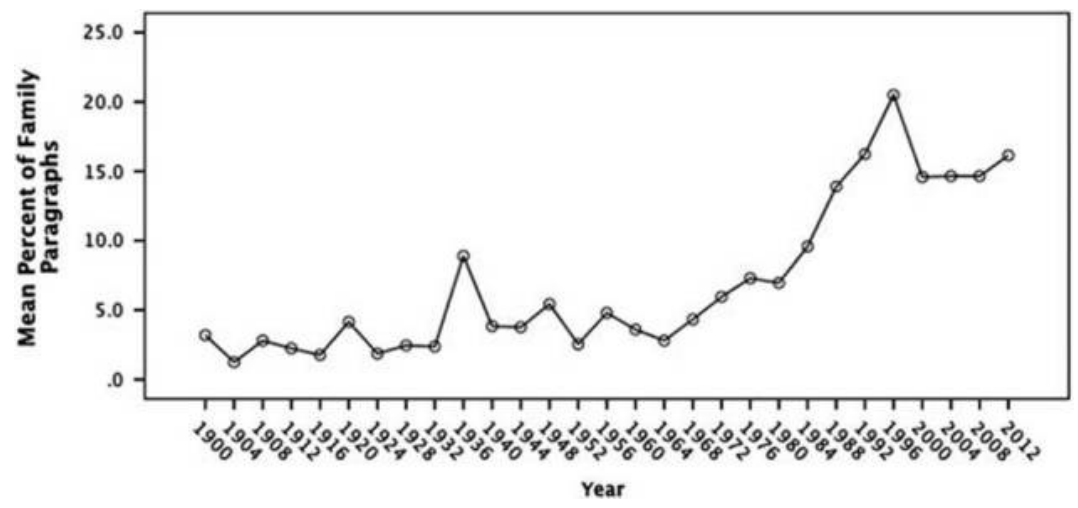

Source: Data compiled by author. $\mathrm{N}=17,489$. See note 13 above in the text of this article for more information about methodology.

Moreover, late twentieth century legislators focused on parenting more than any other family issue. Through the 1990s, legislative bills addressed five policy issues affecting the family: its sexuality, structure, parenting, property and wealth, and public assistance. ${ }^{15}$ The single largest proportion (27\%) of family bills

paragraphs. This yielded 538 bills for the Progressive era (1899-1920), 457 for the Postwar period (1945-1954) and 1028 bills for the late twentieth century period (1989-2004). For instance, both parties' platforms discussed the family in the early twentieth century in pledges on veterans' pensions and homestead policies. I consulted "pensions" and "public lands" headings in the Congressional Record Indexes for the relevant periods.

The period since 1980 is unlike the others insofar as "the family" is now a separate heading in the annual Congressional Record Index listings. In each era, I defined family narrowly and included only those bills whose titles invoked a family relation (spouse, parents, dependents) or an aspect of family life (such as marriage, pregnancy, or family property). For instance, bills whose titles and synopses referred to "women" or "children" only generally and without mention of their family role or context were excluded. It bears noting that the increase in family-related bills in the late twentieth century Congresses could correlate to institutional developments in Congress, such as the increase in the number of subcommittees following legislative reforms in the 1970s. See, for instance, Nelson Polsby, How Congress Evolves: Social Bases of Institutional Change (New York: Oxford University Press, 2004). However, the analysis of institutional dynamics is outside the scope of the study. Instead, my objective is to describe the increased policy attention to family and to analyze its partisan dynamics in terms of discourse, ideology, and politics. Increased attention to family is corroborated by platform data, which shows that the parties increased three-fold the percentage of their platforms devoted to family and family policy issues after 1968, compared with the platforms in the 1900-1968 period.

15. $N=1028$ family-related bills. Through a method of close induction and content analysis of bill titles, I identified that these five categories were the most important ones and then coded each bill as falling primarily in one or the other category. 
sponsored focused on parents, more than the share of bills that highlighted family sexuality (11\%), family structure (17\%), family property/wealth (14\%), and even public assistance (21\%). Parenting thus emerged as a central policy issue of the late twentieth century.

Many scholars have highlighted conservatives' political turn to parents in this period in terms of their privatization of the family and their advocacy of family autonomy from the state. ${ }^{16}$ Barbara Bennett Woodhouse, for example, asserts that religious and political conservatives view parents' rights as "absolute" and "inalienable...natural rights antedating the State." ${ }^{17}$ Resembling the concerns of parents in the Progressive era who had claimed that child labor laws, compulsory education, and vaccination legislation were "improper and unnecessary usurpations of the God-given authority of parents to direct their children's upbringing," Woodhouse writes in the mid 1990s, "today, we see...the same tensions reflected in public debates over family values, children's rights, state intrusions on family prerogatives, and a new drive towards the privatization of the family." 18

Indeed, in congressional hearings and through proposed legislation, Republicans in the 1980s and 1990s resurrected parents as the "missing link" against the state and represented parental authority as crucial to family autonomy. They increasingly advocated that "government should adopt no policy that would drive a wedge between husbands and wives or between parents and their children." ${ }^{19}$ Republican platforms through the 1980s and 1990s attacked prevailing welfare, tax, abortion, education, and consumer laws as part of "the liberal philosophy [that] has assaulted the family on every side," inasmuch as it "den[ies] parental authority and responsibility, fracturing the family into isolated individuals, each of them dependent upon - and helpless before -

16. See, for example, Linda L. Lane, "The Parental Rights Movement," University of Colorado Law Review 69 (1998): 825-50, at 825. Feminist political theorists who highlight equality rightly critique the assumption of family autonomy in liberal theory and emphasize the privatization aspects of family in conservative political discourse, See, for example, Martha A. Fineman, The Autonomy Myth: A Theory of Dependency (New York: New Press, 2005); Maxine Eichner, The Supportive State: Families, Government, and America's Political Ideals (New York: Oxford University Press, 2010); Linda McClain in this symposium, "The Family, the State, and American Political Development as a Big Tent: Asking Basic Questions about Basic Institutions," Polity 48 (2016): 224-42.

17. Barbara Bennett Woodhouse, "A Public Role in the Private Family: The Parental Rights and Responsibilities Act and the Politics of Child Protection and Education," Ohio State Law Journal 57 (1996): 393-430, at 395.

18. Ibid., 395 .

19. Orrin Hatch (R-Utah), Senate Committee on Labor and Human Resources, Private Sector Initiatives: Examination of the Private Sector Initiatives to Promote the Health and Wellbeing of American Families, 98th Cong., 2nd sess., 1983, 1; on the importance of preserving family integrity and autonomy in social policy also see, Jeremiah Denton (R-Ala.), Senate Committee on Labor and Human Resources, Work Ethic: Materialism and the American Family, 97th Cong., 2nd sess., 1982, 7. 
government." ${ }^{20}$ Parental authority for Republican conservatives was thus crucial to maintaining family as the "home of freedom" and limiting the reach of the public sphere into the private. $^{21}$

However, the enhanced political value of parents to late-twentieth-century partisans extended beyond the anti-statist autonomy framework. Instead, Republicans also created an ideal of parents as moral stewards of a traditional social order, whose increased political worth flowed from their role as positive guardians of that cherished order and not merely as negative actors limiting the state. For example, Allan Carlson, director of the influential conservative Rockford Institute and a frequent witness at congressional hearings, called for a "turn to home," because the "family was that social unit that reconciled liberty with order, that kept individual's interests in balance with the interests of community and posterity." ${ }^{22}$ During the same period, the communitarian movement also insisted that "the extreme cultural emphasis in the United States on individual rights, freedom, and self-fulfillment" now required "a cultural shift back toward marital and parental responsibility." ${ }^{23}$ Family and state, or the private and public, comprised a nested hierarchy rather than two distinct spheres, both overlapping in their collective defense of traditional social order.

This conception of parents, as embedded within (and in service to) a public social order, harkens less to the unmoored, autonomous family of neoliberalism and more to the "organic model of the household" that legal historians have attributed to the antebellum Old South. ${ }^{24}$ By paying attention to the influence of this ideational variant of family, we see the deep regionalism of the New Right's conservative agenda and the centrality of family in tying together hierarchical (racial and gendered) ideologies.

20. Republican Party Platforms: "Republican Party Platform of 1992," in Gerhard Peters and John T. Woolley, The American Presidency Project, at www.presidency.ucsb.edu/ws/?pid=25847, accessed August $15,2015$.

21. Ibid.

22. Allan C. Carlson, "The Family and the Constitution," The Family in America 3 (1989): 1-8, at 8.

23. Don Browning, "When Theory Meets Practice: Communitarian Ethics and the Family," in Marriage in America: A Communitarian Perspective, ed. Martin King Whyte (Lanham, Md.: Rowman \& Littlefield Publishers, 2000), 293-300, at 294. For communitarians, rights and responsibilities are "basic moral values" that "should be balanced with one another... at all times and all places." Individual-centered rights thus needed to be counterbalanced against society-centered responsibilities. See Amitai Etizioni's seminal works The New Golden Rule: Community and Morality in a Democratic Society (New York: Basic Books, 1996) and The Spirit of Community: Rights on Responsibilities and the Communitarian Agenda (New York: Crown, 1993).

24. Peter Bardaglio, Reconstructing the Household: Families, Sex, and the Law in the Nineteenth-Century South (Chapel Hill: University of North Carolina Press, 1995). 


\section{RESURGENT PARENTHOOD}

There is now an established body of literature that demonstrates historic and ongoing regional differences in politicized family ideals. ${ }^{25}$ In the "contractual view of domestic relations" emerging in the urbanizing North of the nineteenth century, the family was an increasingly autonomous unit, in which the members of a household (husband-wife, parent-child) were voluntarily "bound together by egalitarianism and affection." In contrast, an "organic domestic ideal" prevailed in the antebellum rural South, based on "traditional notions of patriarchal authority that stressed the importance of harmony, dependency, and hierarchy." ${ }^{26}$ In the Southern view, the household was "embedded in networks of blood, marriage, and kinship [and] provided the key source of order and stability in southern society." ${ }^{27}$ Hierarchical domestic relations in the household, and foremost paternal authority, reflected and reproduced the "organic hierarchy" that was the basis of social order in the slaveholding South. ${ }^{28}$

Yet, the parental or patriarchal authority of the head of household was not considered absolute or universal in the antebellum South. Instead, there existed a widely prevalent "localized" Southern domestic ideology, wherein the authority of patriarchs over their households, including paternal rights over children, was subjected to a metaphorical social "peace," an overarching "public order" that permeated all southern domestic relations. ${ }^{29}$ The preoccupation with maintaining this public order subjected individual parental authority to broader community goals, such that the rights of patriarchs were upheld only in cases where they could demonstrate fulfillment of "their allotted roles within their families and

25. On nineteenth-century differences in Northern and Southern family ideals and/or the distinctiveness of Southern family ideals, see Rebecca Edwards, Angels in the Machinery: Gender in American Party Politics from the Civil War to the Progressive Era (New York: Oxford University Press, 1997), 12-38; Bardaglio, Reconstructing the Household, 82, 84, 117-19 (see previous note); Laura F. Edwards, The People and Their Peace: Legal Culture and the Transformation of Inequality in the Post-Revolutionary South (Chapel Hill: University of North Carolina Press, 2009), 169-86; and Kathleen M. Brown, Good Wives, Nasty Wenches, and Anxious Patriarchs: Gender, Race, and Power in Colonial Virginia (Chapel Hill: University of North Carolina Press, 1996). On regional family ideals in contemporary politics/policy, see Cahn and Carbone, Red v. Blue Families (see note 12 above); and Nicole Mellow, The State of Disunion: Regional Sources of Modern American Partisanship (Baltimore, Md.: Johns Hopkins University Press, 2008), 179.

26. Bardaglio, Reconstructing the Household, xii (see note 24 above). Also, Rebecca Edwards contrasts similar sectional family ideals in her assemblage of the "maternal family ideal" of Republican Protestant Yankees in the nineteenth century, as differentiated from a southern-based Democratic family ideology centered on "domestic male authority," in Angels in the Machinery, 23 (see previous note).

27. Bardaglio, Reconstructing the Household, 23 (see note 24 above).

28. Ibid., 25

29. Edwards, The People and the Peace, 169-201 (see note 25 above). For work extending Edwards's argument to antebellum race determination and patriarchal authority in Louisiana, see Gwendoline Alphonso, "Public \& Private Order: Law, Race, Morality and the Antebellum Courts of Louisiana, 1830-1860," Journal of Southern Legal History 23 (2015): 117-60. See also Ariela Gross, What Blood Won't Tell: A History of Race on Trial in America (Cambridge. Mass.: Harvard University Press, 2008) on the importance of juries, social customs, and norms in the determination of race-based patriarchal authority within the household. 
communities." ${ }^{30}$ Parents, their authority and rights, were thus an organic part of the all-encompassing preoccupation with public social order.

We see a similar focus on organic social order underlying the construction of parents in policy discussions by late twentieth-century Republicans. In numerous congressional hearings on "Teen Pregnancy," "Absentee Fathers," "Alcoholism," "Broken and Disrupted Families," and "Youth Crime and Delinquency," parents were idealized not for their personal, inherently significant, affection or commitment to their children (as per the Northern companionate, contractual view of family). Rather, they were viewed more instrumentally: as moral stewards of their children's destinies, crucial to the continued order of the community and even of the nation. As Senator Jeremiah Denton, newly elected Republican from Alabama asserted in the early 1980s, "lack of parental supervision... affects the child's future, well-being and citizenship in terms of his or her self-respect and respect for authority, with consequent propensities toward such miscreant behavior as alcohol and drug abuse, criminality, and even disloyalty toward country." ${ }^{31}$ In another hearing on Encouraging Responsible Fatherhood, Dan Coats (R-Ind.), also first elected in 1980, highlighted the need to restore the centrality of fathers and paternal authority in order to maintain (traditional) social order, saying that "...a society of unattached males asks for and gets chaos...when the role of fathers is respected and restored, a neighborhood and a society becomes a better place to live." 32

Several newly elected Republican legislators of the New Right, many of them from erstwhile Democratic districts in the South, ${ }^{33}$ now solicited the state to restore parents' traditional roles, to act as "social glue," in the words of Dan Marriott (R-Utah). ${ }^{34}$ Through programs such as parent education classes for teens, single

30. Edwards, People and their Peace, 112-13 (see note 25 above).

31. Senate Committee on Labor and Human Resources, Subcommittee on Family and Human Services, Broken Families: Oversight on the Breakdown of the Traditional Family Unit, Focusing on the Effects of Divorce, Separation, and Conflict within Marriage on Children and on Women and Men, 98th Cong., 1st sess., 1983,3 .

32. Senate Committee on Labor and Human Resources, Subcommittee on Children and Families, Encouraging Responsible Fatherhood: Examining Initiatives to Encourage Responsible Fatherhood, 104th Congress, 2nd sess., 1996, 2.

33. Black and Black highlight the transformation of Southern representatives most clearly, starting with presidential voting during the Goldwater campaign in 1964 and then in congressional voting and partisan identification almost a generation later, beginning in the 1980s and surging in the 1990s in their Rise of Southern Republicans, 11-20 (see note 1 above).

34. House Select Committee on Children, Youth, and Families, Improving American Education: Roles for Parents, 98th Cong., 2nd sess., 1984, 8; see also witnesses' remarks on how exactly parents fulfill social role obligations - through "shared governance," learning "new parenting skills," and so on 10, 41. In this way, Republican members of Congress (and the antebellum Southern domestic ideal) differed from late twentieth-century academic communitarians. Legislators approached parental authority more instrumentally, as a mechanism to enhance the overall social order, whereas communitarian proponents were more deontological, approaching the restoration of parental authority as an intrinsic moral goal. On the 


\section{RESURGENT PARENTHOOD}

mothers, and other at-risk parents, through parental involvement programs in schools, in the military, and elsewhere, and through fatherhood programs and initiatives, the state was seen to have a critical positive role in revitalizing and recreating parental authority, enabling parents to reclaim their role as "decision makers" and "stewards" of their children's values, and destinies. ${ }^{35}$

Parental autonomy or authority then, within the organic family frame, was not a separate, inherently significant, political goal but a vital part of an overarching one: the defense of a traditional social or public order. This was repeatedly illustrated in policy discussions regarding sex and sexuality, such as in debates over public school mandates or programs. Here, conservative Republican legislators claimed parents' traditional roles as "the primary and most important teachers of values to this Nation's school age children" ${ }^{\text {"36 }}$ as the basis for their opposition to health, sexeducation, and contraceptive programs. For instance, Congressman Frank Wolf (R-Va.) described himself as a "father of five children" and stated that "what troubles me deeply about school-based clinics" was when a "parent sends his or her child to school" with the "message that it's wrong to have sex before marriage, and then they enter this school-based clinic....and they see the nurse who is an employee of the local government agency dispensing birth control pills or contraceptives." 37 Thus, parents' roles as autonomous decision makers, as well as the attack on liberal state programs, were presented in terms of upholding a traditional moral order. Parental autonomy and rights were protected only in those cases where the parents abided by that traditionalist creed.

In numerous hearings about television and entertainment rating systems, censorship of movies, and internet pornography, conservative legislators decried also the "pervasive influence" of the "commercial establishment [in] American living rooms." Again, their charge was that this violated traditional social order and parental autonomy, or as one witness described it, "the control of the father over what is being viewed by his children." ${ }^{38}$ Here too, technological change in the late

deontology of communitarian philosophy, see Don Browning, "When Theory Meets Practice," 294-95 (see note 23 above).

35. See, as examples of increasing testimony highlighting parents' stewardship and decision-making role: Statement of Elizabeth McGee, National Child Labor Committee, House Select Committee on Children, Youth, and Families, Teen Parents and Their Children, 98th Cong., 1st sess., 1983, 81; Statement of Elaine M. Amerson, House Select Committee on Children, Youth, and Families, Parents, the Missing Link in Education Reform, 100th Cong., 1st sess., 1987, 15, 17; Statement of Gen. John A. Wickham, Chief of Staff, U.S. Army, House Select Committee on Children, Youth, and Families, Paternal Absence and Fathers' Roles, 98th Cong., 1st sess., 1983, 18.

36. Peter Hoekstra (R-Mich.) Chair, House Committee on Economic and Education Opportunities, Parents, Schools and Values, 1, 41

37. House Select Committee on Children, Youth, and Families, Infancy to Adolescence: Opportunities For Success, 100th Cong., 1st sess., 1987, 110-11.

38. Reverend George W. Hall, Truro Episcopal Church, witness, Senate Committee on Labor and Human Resources, Broken Families, 270 (see note 31 above). See also these examples of other hearings on parents and entertainment censorship: Senate Committee on the Judiciary and Committee on 
twentieth century, the growth of media, and new forms of entertainment were highlighted as upending the otherwise organic traditional social order and the primary (moral and autonomous) role of parents within it.

By the late twentieth century, the "organic domestic order" and its conception of parents could no longer be realized organically and instead required active state intervention. ${ }^{39}$ For the New Right, starting in the 1970s, the renewed focus on parental authority and the urgent need for restoring moral parenting also entailed the active regulation of some groups of parents. Regulation was long an important element of the nineteenth-century Southern domestic order and points to the artificial - even coercive - aspect of a traditional social order based on hierarchy and designated roles, rather than on choice and consent. ${ }^{40}$ Southern legal historians describe the "strong element of coercion that enforced inclusion in this system. Although everyone had a place, coercion was essential to keep people in their places." ${ }^{41}$ They note that Southern jurists' preoccupation with maintaining family stability and regulating racial and gendered hierarchies, particularly in cases of miscegenation and sexuality among poor white and black families; continued to prevail in the post-bellum South despite the infiltration of the contractual model of domestic relations after $1865 .^{42}$

The renewed Republican interest in parents in the late twentieth century also took different forms across different kinds of families. In the case of selfsufficient, traditional families, conservatives focused on parents in order to reassert parental autonomy and authority, while they called for greater regulation and intervention into poor, non-traditional families. In the case of the latter, conservative legislators and the witnesses they called stressed what they saw as a "profound cultural confusion" among parents "about what is responsible

Governmental Affairs, Joint Hearings, Rating Video Games: A Parent's Guide to Games, 103rd Cong., 1st sess., 1993, 1994; Senate Committee on Governmental Affairs, Rating Entertainment Ratings: How Well Are They Working for Parents and What Can Be Done to Improve them? 107th Cong., 1st sess., 2001; and Senate Committee on the Judiciary, Why the Government Should Care About Pornography: The State Interest in Protecting Children and Families, 109th Cong., 1st sess., 2005.

39. After 1865, the end of bondage, the lynchpin of the antebellum Southern domestic order, necessitated an enhanced "state paternalism" in which the state intervened far more extensively into Southern households, such as through the development of external standards of parental evaluation in child custody and protection cases. However, here too, state intervention grew significantly only in those families, particularly those of the indigent, where parents were deemed to have failed in some way; See Bardaglio, Reconstructing the Household, 157-65 (see note 24 above).

40. The regulatory aspect of the emergent conservative parent ideal resembles the enduring "obligation" side of the "rights" coin, as Priscilla Yamin has highlighted in the case of the political construction of marriage in the United States. See her American Marriage: A Political Institution (Philadelphia: University of Pennsylvania Press, 2012).

41. Edwards, People and their Peace, 95 (see note 25 above).

42. Bardaglio, Reconstructing the Household, 79-80, 176-213 (see note 24 above). 
or moral...behavior."43 Hence, they advocated a programmatic cultivation of traditional parental roles, their authority, and their moral stewardship on grounds that many twentieth-century parents, notably low-income, single mothers, were otherwise overly "self" focused. ${ }^{44}$

For example, Rick Santorum (R-Pa.) invited Michelle Simmons to testify at a hearing on "Building Assets for Low-Income Families." She told of her participation in a self-employment training program and how she went from being a "hope-to-die dope fiend, living out of a cardboard box on the streets of L.A." to learning about and practicing budgeting and saving, transmitting the value and discipline of savings to her children. She recounted, "My children used to be like, 'Ma, why are you rushing down to the bank?' I said, 'because I have to get it in by the 31st." " She told her children, "'You have to save every month' " and also observed that "they just learned discipline from that." ${ }^{" 45}$ Through programmatic intervention, voluntary as well as coercive, late twentieth-century conservatives attempted to re-create a social order that would exhort low-income parents, such as Michelle Simmons, to self-sufficiency, and in so doing, recreate traditional parental roles of discipline and authority. ${ }^{46}$

Bill sponsorship data also suggest an increased regulatory element within politicized parental ideals of the late twentieth century. Legislators have been found to typically advance four main types of policies to address family-related problems: welfare policies, seeking to enhance families' economic conditions; regulatory policies, aiming at restricting undesirable family behavior; autonomy policies, promoting family self-sufficiency and independence; and finally, ascriptive policies, encouraging the (white, heterosexual) traditional family through reference to biological ("ascriptive") characteristics, such as race, sex, sexuality, and gender. ${ }^{47}$ In the 101st-108th Congresses (1989-2004), although "parenting" emerged as a dominant focus of the bills in all four of these categories, it did so to the greatest extent in regulatory bills. Large proportions of those classified as welfare or autonomy bills (28\% of each) addressed the family through the frame of "parenting" and a sizeable $14 \%$ of ascriptive bills did this, too. However, among the regulatory bills, the majority (51\%) highlighted parenting as the primary topic of concern.

Just as in the antebellum Old South, in the late twentieth century, parental coercion and regulation were as important to conservatives as were parental

43. Elizabeth A. McGee, House Select Committee on Children, Youth, and Families, Teen Parents and Their Children, 81 (see note 35 above).

44. Denton, Senate Committee on Labor and Human Resources, Broken Families, 107 (see note 31 above).

45. Senate Committee on Finance, Subcommittee on Social Security and Family Policy, Building Assets for Low-Income Families, 109th Cong., 1st Sess., 2005, 5-6.

46. As Senator Santorum asserted, "families where assets are owned, children do better in school, voting participation increases, and family stability improves," Ibid.,157.

47. See Gwendoline Alphonso, "Hearth and Soul: Economic and Cultural Conceptions of the Family in the Progressive Era, 1900-1920," Studies in American Political Development 24 (2010): 206-32, at 213-19. 
autonomy and authority in defense of an idealized "organic social order." In myriad proposals by Republican legislators and their allies, the renewal of parental authority meant strict regulatory control of those who did not (or could not) follow allotted parental roles. There were proposals for wage garnishment and other child support enforcements targeting "deadbeat dads," bills calling for a halt to welfare checks for single, poor (often minority) mothers who had extra-marital births, and proposals that sought to impose work requirements for families receiving public assistance. Several policy discussions centered on re-asserting a strong role for the father, who was described as having better moral and financial judgment than single, unattached mothers. ${ }^{48}$ Thus, legislators, such as Senator Lauch Faircloth (R-N.C.), proposed welfare reform wherein "we are going to have to almost make it...that if the father is not in the home, you do not get the money." ${ }^{" 9}$ The (Southern) organic family framework, with its emphasis on parental and paternal authority, social order, and allotted family roles, along with parents' autonomy and rights, thus reverberated among Republicans' politicized ideals of parents and in the complex ways in which parents came to be deployed in legislative discourse and bills.

The late twentieth-century emphasis on parents in service of a traditional social order illustrates ways in which the relationship between family and state has both endured and changed since the immediate postwar era. In that period, too, policymakers had been preoccupied with the regulation of "deficient" parental behavior and the creation of welfare programs to educate and reform deficient parents. ${ }^{50}$ Numerous "runaway pappy" bills and programs for "parent education classes" suggest that the legislative construction and reification of roles and ideals of parenthood were central to the politics of the family in the decade following World War II. ${ }^{51}$ However, as seen in the bill sponsorship data from the 1990s, in the late twentieth century the preoccupation with parents ratcheted up particularly in regulatory family bills, with a majority of such bills

48. See for instance, Charles Ballard, President National Institute for Responsible Fatherhood, in Responsible Fatherhood, 38-39 (see note 32 above). For other examples of Republican preferences for traditional gender roles in family, with the wife as primary caregiver, see Dan Coats (R-Ind.), House Select Committee on Children, Youth, and Families, Absence, 2 (see note 35 above); Jeremiah Denton (R-Ala.), Senate Committee on Labor and Human Resources, Broken Families, 108-09,126-27 (see note 31 above), on how gender role reversals result in psychosexual and gender disturbances; and personal anecdote by Dave Weldon (R-Fla.), House Committee on Economic and Educational Opportunities, Subcommittee on Oversight and Investigations, Parents, Schools and Values, 104th Cong., 1st sess., 1995, 30.

49. Senate Committee on Labor and Human Resources, Encouraging Responsible Fatherhood, 39 (see note 42 above).

50. Alphonso, Polarized Families, Polarized Politics, Chapter 3 (see note 9 above).

51. See, for instance, House Subcommittee No. 2 of the Committee on the Judiciary, Making Abandonment of Dependents a Federal Crime, 81st Cong. 1st and 2nd sess., 1949, 1950; and generally, William J. Brockelbank and Felix Infausto, Interstate Enforcement of Family Support (The Runaway Pappy Act), (Indianapolis, Ind.: Bobbs-Merrill Co., 1971). 
now directed at parents. Moreover, parents also emerged as a significant focus of autonomy policies. This demonstrates the growing overlap between parental authority and autonomy, on the one hand, and the preservation of social order and regulation of parental roles, on the other. These policy developments underscore the significance of (Southern) organic domestic ideals in the late twentieth century, wherein parental autonomy and role regulation both coexisted in defense of social order.

\section{The Southern Roots of the New Right's Family Ideals}

The New Right's turn to family and to parents, and its increasing embrace of an organic social order coincided with changes in the Republican Party's electoral base, namely its shift to the South. Although scholarship is divided on the cultural distinctiveness of the modern South, ${ }^{52}$ late twentieth-century Southerners, as a social and electoral group, continued to share a conservative political identity, with policy preferences distinctive from Americans in the North and Pacific Coast. ${ }^{53}$ Election results and survey research data demonstrate racial divisions between white and black Southerners, but they also suggest marked continuing differences between North and South as a whole, evidencing that "Southerners as a group appear to be more socially conservative, nationalistic, and religious than non-Southerners.... They also seem to be better satisfied, regardless of class, race, or party, with their states and communities than is true of other Americans."

In addition, Southerners have experienced, interpreted, and perceived the breakdown of the nuclear family different than non-Southerners have. ${ }^{55}$ Scholars have found that "the change in family structure has been most dramatic for...the communities [in red states mostly in the South and along the southern border] that most revolve around marriage, where divorce has consequences not just for

52. For interpretations stressing the convergence of the South with other regions see, for example, Byron Shafer and Richard Johnston, The End of Southern Exceptionalism: Class, Race, and Partisan Change in the Postwar South (Cambridge, Mass.: Harvard University Press, 2006); Sean P. Cunningham, American Politics in the Postwar Sunbelt: Conservative Growth in a Battleground Region (New York: Cambridge University Press, 2014). For accounts emphasizing its continued distinctiveness as a region, see all the references in note 1 above and also Geoffrey Kabaservice, Rule and Ruin: The Downfall of Moderation and the Destruction of the Republican Party, from Eisenhower to the Tea Party (New York: Oxford University Press, 2012).

53. Ann Markusen, Regions: The Economics and Politics of Territory (Lanham, Md.: Rowman \& Littlefield, 1987); J.S. Hurlbert, "The Southern Region: A Test of the Hypothesis of Cultural Distinctiveness," Sociological Quarterly 30 (1989): 245-66.

54. Alan Abramowitz, "Ideological Realignment and the Nationalization of Southern Politics," in Perspectives on the American South: An Annual Review of Society, Politics and Culture, vol. 1, ed. Merle Black and John Shelton Reed (New York: Gordon \& Breach, 1981), 83-106.

55. Cahn and Carbone, Red Fs v. Blue Families, 19-32 (see note 12 above). 
individual well-being but...for the foundations of shared notions of morality." ${ }^{56}$ Marked attachment to place, to shared identity, community, and family distinguish southerners from other Americans, ${ }^{57}$ suggesting the ongoing resonance of the organic family frame among them.

The increasing salience of the South and Southern family experiences to the New Right is evidenced in the family anecdotes used by Republican legislators during committee hearings. During committee hearings, members of Congress and their invited witnesses frequently recount "real life" families as policy examples, highlighting certain characteristics and circumstances of their lives, including where they resided ${ }^{58}$ From 1981 to 2006 , Republican legislators drew on families from the South, more than from any other region, to illustrate their policy positions, while Democrats referred mostly to families from the North. ${ }^{59}$ Of the families used in examples that Republicans referred to during this period, $43 \%$ lived in the South, while $42 \%$ of family cases discussed by Democrats were from the North; the differences in proportions were statistically significant (see Table 1). ${ }^{60}$

Far more than in the Democrats' anecdotes, the Republicans' family examples highlighted enduring family-social networks, extended kin, inherited social values, and robust community life - all hallmarks of the socially embedded, Southern organic family ideal. Of the family examples that discussed families' social connectedness, $58 \%$ of Republican cases stressed civic participation in voluntary organizations, versus 36\% of Democratic family examples. These qualities were qualitatively epitomized in the account of family life provided by Timothy Vann, a widowed mother of ten children (with an unusual name), whose family was honored in 1983 by Nancy Reagan and the evangelical American Family Society as a "Great American Family." Mrs. Vann testified before the Senate Subcommittee on Family and Human Services and attributed "successes and achievements made by my family" to "...my parents, my grandparents, and my friends" and to the fact that

56. Ibid., 119 (emphasis added).

57. John Shelton Reed, "The South: What is it? Where is it?" in The South for New Southerners, ed. Paul D. Escott and David R. Goldfield (Chapel Hill: University of North Carolina Press, 1991), 18-41; also see Dewey W. Grantham, The South in Modern America: A Region at Odds (New York: Harper Collins Publishers, 1994), 313; Earl Black and Merle Black, Politics and Society in the South (Cambridge, Mass.: Harvard University Press, 1987), 219-29.

58. See note 9 above for case selection and methodology.

59. The coding of regions aggregates Census Divisions: where North $=$ Census Divisions of New England, Middle Atlantic and East North Central; South = all of Census Region of South, that is Divisions of South Atlantic, East and West South Central; West = Mountain and West North Central Divisions; and Pacific $=$ Pacific Division; see: $w w w 2 . c e n s u s . g o v / g e o / p d f s / m a p s-d a t a / m a p s / r e f e r e n c e / u s \_r e g d i v . p d f$, accessed January 16, 2016. For a similar aggregation also analyzing the significance of region to partisan development, albeit without the inclusion of Hawaii, Alaska, or the District of Columbia, see Mellow, The State of Disunion, 26-27 (see note 25 above).

60. The Pearson's Chi-Square Statistic of "Region of Family Residence" with "Party of Active Member of Congress" is $13.8, \mathrm{p}=.003$. 
Table 1

Republican and Democratic Family Case Examples by Region of Family Residence, 1981-2006

\begin{tabular}{|c|c|c|c|c|c|}
\hline & & \multicolumn{4}{|c|}{ Party of Active Member of Congress } \\
\hline & & \multicolumn{2}{|c|}{ Democratic } & \multicolumn{2}{|r|}{ Republican } \\
\hline & & Count & Column $N(\%)$ & Count & Column $N(\%)$ \\
\hline Region of Family & North* & 283 & 42.2 & 140 & 33.7 \\
\hline \multirow[t]{3}{*}{ Residence ${ }^{* *}$} & South* & 216 & 32.2 & 179 & 43.0 \\
\hline & West & 81 & 12.1 & 49 & 11.8 \\
\hline & Pacific & 90 & 13.4 & 48 & 11.5 \\
\hline
\end{tabular}

*Values in the same row are significantly different for Democratic and Republican cases at $p<0.05$ in the two-sided test of equality for column proportions. Tests assume equal variances.

$* * \chi^{2}$ statistic is significant at the 0.05 level

Source: Data compiled by author from congressional hearings. See note 14 in the text of this article for more information about methodology

"we inherited the good Southern tradition of discipline, work, respect for parents and elderly...the teachings of love and honor for God, respect for my parents, respect and consideration of all people, honesty, industriousness, self-reliance and self-worth were passed to me and then, on to my children." ${ }^{61}$

Parental authority and discipline, which also were central features of the traditional organic family frame, have continued to be rated highly by late twentieth-century Southerners and by Republican legislators and the witnesses they called in congressional hearings. Survey research shows that instilling a sense of order and respect for authority among children has been highly important to Southern parents across socio-demographic groups, who surpass all other regional groups in their support of the use of force to insure appropriate behavior in their children. ${ }^{62}$ In a similar vein, Republican members of Congress constructed stern parental authority in their family cases by stressing ideals of order and discipline. ${ }^{63}$

61. Senate Subcommittee on Family and Human Services of the Committee on Labor and Human Resources, Forum for Families: Quality of American Family Life, 98th Cong., 1st sess., 1983 (emphasis added).

62. Clifton P Flynn, "Regional Differences in Attitudes Towards Corporal Punishment," Journal of Marriage and the Family 56 (1994): 314-24.

63. See, for example, Jim DeMint (R-S.C.) House Subcommittee on Early Childhood, Youth, and Families of the Committee on Education and Workforce, School Safety, Discipline, and IDEA, 106th Cong., 1st sess., 1999, 4, as well as many family stories, including testimony by Christopher Lyle in House Subcommittee on Early Childhood, Youth, and Families of the Committee on Education and Workforce, School Violence: Views of Students and The Community, 106th Cong., 1st sess., 1999. 
In fact, members of both parties in recent Congresses have drawn an increasing share of their family examples from the South, suggesting the rising salience of the South to both parties' policy ideologies in the late twentieth century. While the number of family stories from the South remained relatively high, those from the North declined precipitously beginning in the mid-1990s, when the Republicans issued their Contract with America and took control of Congress (see Figure 2).

More generally, the salience of Southern families in policy discourse strongly matches the shifting electoral fortunes of the Republican Party in Congress, suggesting the centrality of Southern families to Republicans' policy agenda, much more than for the Democratic Party. As Reagan Republicans, such as Senator Denton from Alabama or Frank Wolf from Virginia, entered Congress in the early 1980s (in the 97th-99th Congresses), the largest proportion of total family examples discussed during hearings hailed from the South. Again, at the height of Republican strength, when Republicans dominated both chambers in Congress (in the 104-106th Congresses, 1996-2002), families from the South and the Mountain West (i.e., the so-called red states), were again those most often referred to in policy debates, indicating their enhanced political value to the Republican coalition.

Figure 2

Region of Families Referenced in Hearings, 97th-109th Congresses (1981-2006)

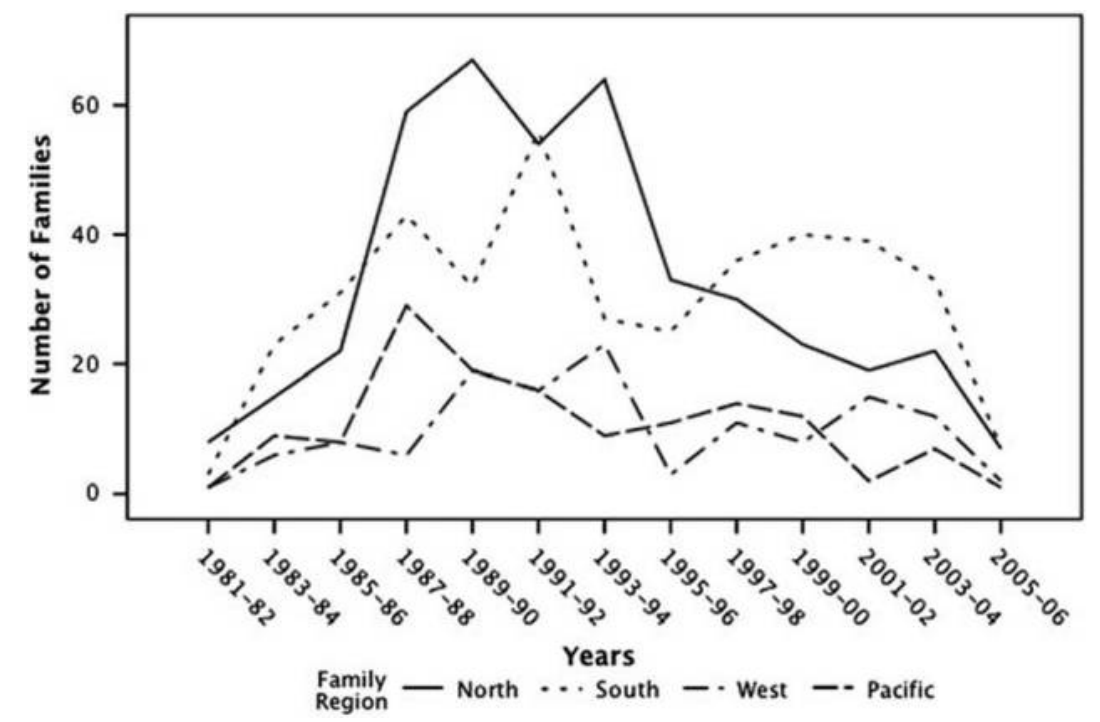

Source: Data compiled by author. See note 14 above in the text of this article for more information about methodology. 
In contrast, in the mid-1980s to early 1990s, when Democrats and Republicans battled for control over the two chambers in Congress, family examples from the blue states of the North and Pacific Coast were referred to in numbers comparable to those from the red, Southern and Mountain, states. Thus, data on the use of family examples in hearings empirically demonstrate that families from the South, although increasingly referred to by legislators from both parties in the last decade of the twentieth century, had the greatest political value for Republican legislators, since their presence in congressional hearings ebbed and flowed depending on Republican strength in Congress. The resurgence of parents as a political ideal was part of this increasing southernization of Republican family ideology and the exportation of policies and ideas from the South to the national electorate and American party politics.

\section{Conclusions}

This article has presented a family-centered account of the Republican Southern strategy of the late twentieth century. By invoking the organic family frame and its autonomous yet regulated parent subject, New Right Republican legislators increasingly accommodated the family policy ideals of the Southern electorate. Family served as the ideational site or terrain that shaped and facilitated the southernization of political change within the Republican Party. By focusing on ideational and discursive innovations as the locus of significant partisan shifts, my account contributes to recent innovations in scholarship on American political development that do not solely focus on institutions and governance structures, but highlight instead the significance of language, ideas, and culture in influencing political change. ${ }^{64}$ Family ideals, although mediated by institutional contexts (such as party structures) play a decisive role in shaping political party development.

Also significant for the American political development literature is the demonstration of family as both a public and private institution, whose public or political value depends on private family experiences as seen through the family examples cited by legislators during committee hearings. I present the political development of family as the outcome of social (family demographic) and political (party) institutional dynamics. With the revival of Southern organic family ideals in the late twentieth century, the blurring of public and private family boundaries in public policy became all the more vivid, as conservative policymakers' concern to uphold private parental rights and autonomy occurred at the same times that they

64. See, for example, Rogers M. Smith, Political Peoplehood: The Roles of Values, Interests, and Identities (Chicago: University of Chicago Press, 2015): also, Victoria Hattam and Joseph Lowndes, "The Ground Beneath Our Feet: Language, Culture, and Political Change," in Formative Acts: American Politics in the Making, ed. Stephen Skowronek and Matthew Glassman (Philadelphia: University of Pennsylvania Press, 2007), 199-219. 
attempted to harness the public regulation of parental roles and parental autonomy in defense of a public social order.

Additionally, this account complicates the picture of the Republican Southern strategy as merely an elite-driven phenomenon formulated by conservative political strategists and evangelical leaders. It instead underscores the importance of the Southern social context in which organic family ideals had long been prevalent - and without which the very politicization of conservative family ideals by the New Right would not have been viable. Family political ideals are rooted in distinct social realities, and overlooking their social contexts misses the lived regionalism that underlies partisan family appeals and political strategies. As the Republican Party moved south, it increasingly incorporated Southern family experiences to craft its policy agenda, while Democratic legislators, although acknowledging Southern families, continued to rely mostly on examples of families in the postindustrial Northeast.

The entrenchment of political family ideals within differing social realities has broader implications for twenty-first century social policy. To the extent that lived family experiences, and imbricated family values, in Red and Blue America continue to diverge, as most experts predict they will, the analysis here suggests that the parties will remain firmly polarized in their policy preferences and agendas. Public policy literature that focuses on family and social policy must take this sectional reality into consideration when suggesting new policy directions.

Finally my analysis suggests that the resurgence and politicization of parents was an important part of a family-centered Republican Southern strategy, coincident to family demographic change. Conventional explanations of party change limit their analysis to shifts in income distribution, immigration, and race within the American electorate. ${ }^{65}$ Family change, in terms of its form and/or conceptualization, plays almost no role in these accounts, and family policy ideals are often subsumed into the catch-all category of emergent "social" issues. This contribution hopes to begin to fill this gap by placing "family," as a policy and ideological issue, at the heart of late twentieth-century party politics and development.

Gwendoline M. Alphonso is Assistant Professor of Politics at Fairfield University. She has published articles in Studies in American Political Development, the Journal of Policy History, the Journal of Southern Legal History, Children and Youth During the Gilded Age and Progressive Era (ed. James Marten, NYU Press, 2015), and in several law journals. Her forthcoming book, Polarized Families, Polarized Parties, demonstrates the central role of family in shaping political party development across the twentieth century.

65. See, for example, Mark D. Brewer and Jeffrey M. Stonecash, Dynamics of American Political Parties (New York: Cambridge University Press, 2009). 